\title{
STABLE ISOTOPE/TEST SIZE RELATIONSHIP IN Cibicidoides wuellerstorfi
}

\author{
Paula Franco-Fraguas*, Karen Badaraco Costa and Felipe Antonio de Lima Toledo \\ ${ }^{1}$ Instituto Oceanográfico da Universidade de São Paulo \\ (Praça do Oceanográfico, 191, 05508-120 São Paulo, SP, Brasil) \\ *Corresponding author: paulafrancof@gmail.com
}

Descriptors: Stable isotopes, Test size, Cibicidoides wuellerstorfi.

Descritores: Isótopos estáveis, Tamanho testa, Cibicidoides wuellerstorfi.

Stable isotope $\left(\delta^{18} \mathrm{O}\right.$ and $\left.\quad \delta^{13} \mathrm{C}\right)$ measurements in foraminifera tests are widely used for paleoceanographic interpretations (WEFER et al., 1999; ROHLING; COOKE, 1999). This is attained since during calcification foraminifera registered in their tests the stable isotope signature and environmental conditions of seawater of their local of calcification in a somehow predictable way (ROHLING; COOKE, 1999).

Foraminifera test size is an important source of stable isotope variability found in sediment samples. Some of this variability is associated to foraminifera physiological effects (e.g., symbiotic photosynthesis, respiration and calcification) which can vary along ontogeny and affect stable isotope measurements in foraminifera tests (ZEEBE et al., 1999). Regional environmental variables can also affect simultaneously both stable isotope values and foraminifera test size resulting in another source of test size/stable isotope variability (DEUSER et al., 1981). Although it is especially important in planktonic foraminifera (RAVELO; FAIRBANKS, 1995), some studies have found test size/stable isotope variation in benthic foraminifera (CORLISS et al., 2002). This test size/stable isotope variability can result in offsets from predicted values having important implications when choosing test size fractions for paleoceanographic interpretations (OPPO; FAIRBANKS, 1989).

Cibicidoides wuellerstorfi is an epibenthic foraminifera species of great importance in stable isotopic paleoceanographic studies (MACKENSEN; LICARI, 2003). Nevertheless its paleoceanographic importance no stable isotope $\left(\delta^{18} \mathrm{O}\right.$ and $\left.\delta^{13} \mathrm{C}\right)$ test size relationship studies in this species are found in the literature.

Generally $\delta^{13} \mathrm{C}$ measurements in $C$. wuellerstorfi are related in a 1:1 ratio with $\delta^{13} \mathrm{C}$ values in deep water $\left(\delta^{13} \mathrm{C}_{\text {DIC }}\right)$ (MACKENSEN; LICARI, 2003). Positive $\delta^{13} \mathrm{C}$ offsets in $C$. wuellerstorfi have been observed in regions of high surface productivity and low carbonate sediment concentration and were explained by the undersaturation of bottom water conditions (MACKENSEN; LICARI, 2003). In some oligotrophic regions, including the Brazilian Continental Margin, positive $\delta^{13} \mathrm{C}$ offsets have been observed for this species (MCCORKLE et al., 1998; OPPO; HOROWITZ, 2000) and are yet not explained.

If local environmental conditions induce $C$. wuellerstorfi test size /stable isotope related variability in the study area it may be possible that the positive $\delta^{13} \mathrm{C}$ offset observed for this species in the region is result of the test size fraction selected for these studies. The present work explored stable isotope $\left(\delta^{18} \mathrm{O}\right.$ and $\left.\delta^{13} \mathrm{C}\right)$ relationship with test size fractions of $C$. wuellerstorfi and its relation with predicted values of calcite in equilibrium with deep water $\left(\delta^{18} \mathrm{O}_{\mathrm{EQ}}\right.$ and $\delta^{13} \mathrm{C}_{\text {DIC }}$ ) in three core top samples of the Brazilian Continental Margin in order to verify if $\delta^{13} \mathrm{C}$ offsets observed in the region can be explained by the $\delta^{13} \mathrm{C}$ variation related to size.

Piston core KF-G was recovered at 1957 meters water depth at $20^{\circ} 51^{\circ} \mathrm{S}, 39^{\circ} 08^{\circ} \mathrm{W}$ in the South Atlantic Brazilian Continental Margin (southwestern South Atlantic). Three core top samples were selected: $1.5 \mathrm{~cm}, 9 \mathrm{~cm}$ and $16 \mathrm{~cm}$. Accelerator Mass Spectrometer (AMS) radiocarbon dating was performed on Globigerinoides ruber tests of sample $1.5 \mathrm{~cm} . \delta^{18} \mathrm{O}$ values in $C$. wuellerstorfi were used to check Holocene interglacial conditions of $9 \mathrm{~cm}$ and $16 \mathrm{~cm}$ samples (COSTA et al., 2006).

Samples were washed with distilled water in $63 \mu \mathrm{m}$ mesh size and dried at $50^{\circ} \mathrm{C}$. Samples were then separated in four mesh size ranges: $150-250 \mu \mathrm{m}, 250-$ $300 \mu \mathrm{m}, 300-355 \mu \mathrm{m}$ and $>355 \mu \mathrm{m}$. Stable isotope measurements were conducted in single $C$. wuellerstorfi test. Replicate samples were performed in the $150-250 \mu \mathrm{m}$ size fraction.

Stable isotopes analyses were made in Woods Hole Oceanographic Institution micropaleontology laboratory using a Finnigan MAT253 mass spectrometer. Isotope values are represented in standard $\delta$ notation relative to the Vienna Pee Dee Belemnite (PDB) for calcite and Vienna Standard-Mean-Water (VPDB) for sea water. Calibration of the PDB is via the NBS-19 and the precision is \pm 0.07 for $\delta^{18} \mathrm{O}$ and \pm 0.03 for $\delta^{13} \mathrm{C}$.

Annual temperature and salinity data from deep water in a station close to KF-G location (WOAKF-G; $14.5^{\circ} \mathrm{S}, 38.5^{\circ} \mathrm{W}$ ) were obtained from the World Ocean Atlas, 2005 (WOA05) (LOCARNINI et al., 2006; ANTONOV et al., 2006). These data was 
used for identifying deep water mass based on Silveira et al. (2000), for estimating stable oxygen isotopes values in seawater $\left(\delta^{18} \mathrm{O}_{\mathrm{W}}\right)$ and in equilibrium with seawater $\left(\delta^{18} \mathrm{O}_{\mathrm{EQ}}\right) \cdot \delta^{18} \mathrm{O}_{\mathrm{W}}$ was estimated based on annual salinity WOA05 data and $\delta^{18} \mathrm{O} /$ salinity NADW equation from Legrand and Schmidt (2006). $\delta^{18} \mathrm{O}_{\mathrm{EQ}}$ was estimated based on $\delta^{18} \mathrm{O}_{\mathrm{W}}$ and annual temperature WOA05 using Kim and O'Neil (1997) paleotemperature equation. $\delta^{18} \mathrm{O}_{\mathrm{EQ}}$ (SMOW) was converted to $\delta^{18} \mathrm{O}_{\mathrm{EQ}}$ (VPDB) after Hut (1987). $\delta^{13} \mathrm{C}_{\mathrm{DIC}}$ was obtained from a deep water GEOSECS station 55 $\left(18^{\circ} \mathrm{S}, 31^{\circ} \mathrm{W}\right)$ (BAINDBRIDGE, 1981) next to the core location.

In general, $\delta^{18} \mathrm{O}$ measurements in foraminiferal tests have less offsets from predicted values than $\delta^{13} \mathrm{C}$ measurements (GROSSMAN, 1987). Moreover, in the study area C. wuellerstorfi calcify in $\delta^{18} \mathrm{O}$ equilibrium with seawater using Kim and O'Neil (1997) paleotemperature equation (COSTA et al., 2006). measured in $C$. wuellerstorfi were compared with $\delta^{18} \mathrm{O}_{\mathrm{EQ}}$ and $\delta^{13} \mathrm{C}_{\mathrm{DIC}}$, respectively from the location and depth of KF-G core in order to evaluate offsets from predicted values.

Core top location is bathed by North Atlantic Deep Water (NADW) waters (Table 1). No systematic stable isotopic $\left(\delta^{18} \mathrm{O}\right.$ and $\left.\delta^{13} \mathrm{C}\right)$ change with test size fraction was observed (Fig. 1). Radiocarbon dating confirmed Holocene age for sample $1.5 \mathrm{~cm}$ (3540 radiocarbon age, 3482 calendar age). C. wuellerstorfi $\delta^{18} \mathrm{O}$ mean values are in equilibrium with $\delta^{18} \mathrm{O}_{\mathrm{EQ}}$ values $\left(\Delta \delta^{18} \mathrm{O}\right.$ values between $-0.05 \%$ ond $0.09 \%$ o (Table 1, Fig. 1) corroborating with the radiocarbon data and indicating that all three core top samples are representative of Holocene conditions (COSTA et al., 2006). $\delta^{13} \mathrm{C}$ mean values are higher than $\delta^{13} \mathrm{C}_{\mathrm{DIC}}$ values $\left(\Delta \delta^{13} \mathrm{C}\right.$ values between $+0.24 \%$ o and $+0.33 \%$ o (Table 1, Fig. 1). Maximum intraspecific variability (i.e. between a single size fraction and between size fractions) is $0.34 \%$ and $0.29 \%$ for $\delta^{18} \mathrm{O}$ and $\delta^{13} \mathrm{C}$, respectively.

Table 1. $\delta^{18} \mathrm{O}(\% \circ)$ and $\delta^{13} \mathrm{C}(\% \circ)$ measurements in $C$. wuellerstorfi test size fractions. $\Delta \delta^{18} \mathrm{O}$ and $\Delta \delta^{13} \mathrm{C}$ values are $\delta^{18} \mathrm{O}_{\mathrm{EQ}}$ and $\delta^{13} \mathrm{C}_{\text {DIC }}$ values subtracted from mean test $\delta^{18} \mathrm{O}$ and $\delta^{13} \mathrm{C}$ measurements, respectively.

\begin{tabular}{|c|c|c|c|c|c|c|c|}
\hline Sample depth & Test size fraction $(\mu \mathrm{m})$ & Replicates & No. tests & $\delta^{18} \mathrm{O}$ & $\Delta \delta^{18} \mathrm{O}$ & $\delta^{13} \mathrm{C}$ & $\Delta \delta^{13} \mathrm{C}$ \\
\hline \multicolumn{8}{|l|}{$1,5 \mathrm{~cm}$} \\
\hline & $150-250$ & 3 & 1 & 2,85 & & 1,25 & \\
\hline & $150-250$ & & 1 & 2,94 & & 1,43 & \\
\hline & $150-250$ & & 1 & 2,79 & & 1,28 & \\
\hline & $250-300$ & 1 & 1 & 2,79 & & 1,36 & \\
\hline & $300-355$ & 1 & 1 & 2,86 & & 1,34 & \\
\hline Mean & & & & 2.85 & 0.09 & 1.33 & 0.33 \\
\hline stdev & & & & 0.06 & & 0.07 & \\
\hline \multicolumn{8}{|l|}{$9 \mathrm{~cm}$} \\
\hline & $150-250$ & 2 & 1 & 2,72 & & 1,25 & \\
\hline & $150-250$ & & 1 & 2,77 & & 1,37 & \\
\hline & $250-300$ & 1 & 1 & 2,79 & & 1,21 & \\
\hline & $300-355$ & 1 & 1 & 2,64 & & 1,16 & \\
\hline & $>355$ & 1 & 1 & 2,63 & & 1,21 & \\
\hline Mean & & & & 2.71 & -0.05 & 1.24 & 0.24 \\
\hline stdev & & & & 0.07 & & 0.08 & \\
\hline \multicolumn{8}{|l|}{$16 \mathrm{~cm}$} \\
\hline & $150-250$ & 3 & 1 & 2,85 & & 1,39 & \\
\hline & $150-250$ & & 1 & 2,62 & & 1,15 & \\
\hline & $150-250$ & & 1 & 2,91 & & 1,44 & \\
\hline & $250-300$ & 1 & 1 & 2,82 & & 1,28 & \\
\hline & $300-355$ & 1 & 1 & 2,61 & & 1,38 & \\
\hline & $>355$ & 1 & 1 & 2,58 & & 1,23 & \\
\hline Mean & & & & 2.73 & -0.03 & 1.31 & 0.31 \\
\hline stdev & & & & 0.14 & & 0.11 & \\
\hline NADW $(2000 \mathrm{~m})$ & $\mathrm{T}=3.3^{\circ} \mathrm{C}$ & $\mathrm{S}=34.9 \% 0$ & $\delta^{18} \mathrm{O}_{\mathrm{W}}=0.07 \%$ & $\delta^{18} \mathrm{O}_{\mathrm{EQ}}=2.76 \%$ & & $\delta^{13} \mathrm{C}_{\mathrm{DIC}}=1 \% \circ$ & \\
\hline
\end{tabular}



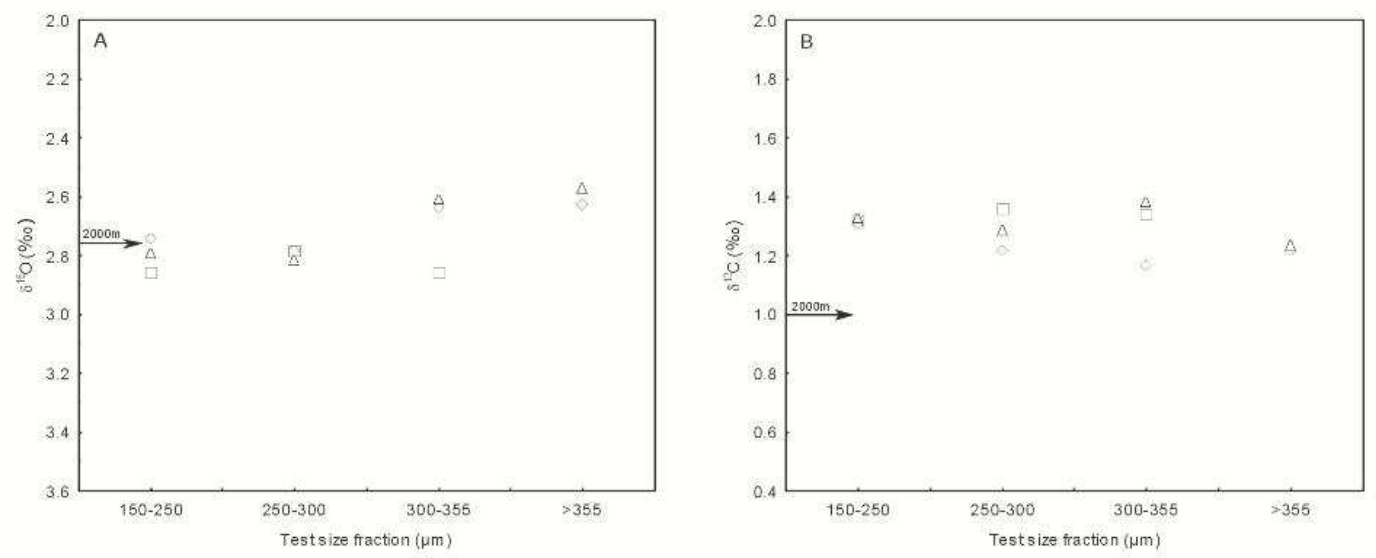

Fig. 1. Mean (A) $\delta^{18} \mathrm{O}$ and (B) $\delta^{13} \mathrm{C}$ measurements in C. wuellerstorfi in core KF-G related to test size fraction. In left margins $\delta^{18} \mathrm{O}_{\mathrm{EQ}}$ (A) and $\delta^{13} \mathrm{C}_{\mathrm{DIC}}$ (B) values obtained at 2000 water depth are shown for comparison with foraminifera measurements.

As opposed to planktonic foraminifera where size related stable isotope variability is generally observed (RAVELO; FAIRBANKS, 1995; ELDERFIELD et al., 2002), few deep sea benthic foraminifera species have shown stable isotope variation with test size (SCHMIEDL et al., 2004; MCCORKLE et al., 2008). Variation in the stable isotope signature of different size fractions of deep sea foraminifera are explained by one of two mechanisms. One the one hand, kinetic fractionation during calcification of foraminifera tests and/or the incorporation of metabolic $\mathrm{CO}_{2}$ during calcification can modify the stable isotope signature registered in foraminifera tests (WOLF-GLADROW et al., 1999). Then, variable metabolic rates during ontogeny can be reflected in stable isotope variability related to test size (BERGER et al., 1978; DUNBAR; WEFER, 1984) Other possibility is that fossil foraminifera in a sample represent a range of ages and that different local environmental conditions prevailing over an interval of time (e.g., organic matter fluxes) preferentially affect any particular size fraction (CORLISS et al., 2002). In epibenthic deep sea foraminifera no stable isotope variation with test size has been observed (VINCENT et al., 1981; DUNBAR; WEFER, 1984; CORLISS et al., 2002). This has been attributed to the low temperature and stability of deep sea together with longer life cycles and slower growth rates of deep sea benthic foraminifera when compared to planktonic foraminifera (SCHMIEDL et al., 2004). The lack of test size stable isotope variation in $C$. wuellerstorfi observed in this study corroborated other epibenthic findings and suggests low ontogenetic related physiological effects and/or lack of local environmental size related control for this species in the region. Moreover, it indicates that the test size fraction is not a limiting factor for paleoceanographic studies based on oxygen and carbon stable isotopes values of $C$. wuellerstorfi.

In general the number of deep sea benthic foraminifera tests is a limiting factor for paleoceanographic studies. Thus, paleoceanographic interpretations using stable isotope measurements in deep sea benthic foraminifera usually use between one and three tests per stable isotope analysis (e.g. CORLISS et al., 2002; MACKENSEN; LICARI, 2003; COSTA et al., 2006). The stable isotope analysis of single test reflects maximum stable isotope variability (BILLUPS; SPERO, 1995). In this case single test analyses (both within a single size fraction and between test size fractions) indicate relatively low oxygen $(0.34 \% o)$ and carbon $(0.29 \%$ ) stable isotope intraspecific variability. However, improvement in paleoceanographic precision can be obtained using more than one test per analysis.

C. wuellerstorfi stable isotopes range of variation from predicted equilibrium generally accepted in the literature is $\pm 0.2 \%$ o for both $\delta^{18} \mathrm{O}$ (COSTA et al., 2006) and $\delta^{13} \mathrm{C}$ (MACKENSEN; LICARI, 2003). Present offset observed for $C$. wuellerstorfi $\left(\Delta \delta^{18} \mathrm{O}\right.$ values between $-0.05 \%$ and $0.09 \%$ ) indicates calcification in equilibrium with bottom water $\delta^{18} \mathrm{O}$ and temperature and are in agreement with other studies developed in the region (COSTA et al., 2006). In the study area, positive $\delta^{13} \mathrm{C}$ offsets (from +0.2 to $+0.5 \%$ ) have been observed in both live and dead $C$. wuellerstorfi tests (OPPO; HOROWITZ, 2000) and are yet not understand. Present $C$. wuellerstorfi $\delta^{13} \mathrm{C}$ offsets observed $\left(\Delta \delta^{13} \mathrm{C}\right.$ values between $+0.24 \%$ and $+0.33 \%$ ) give support to these findings and indicate that test size fraction can not explain this positive $\delta^{13} \mathrm{C}$ offset since $\delta^{13} \mathrm{C}$ values of all size fractions were higher than $\delta^{13} \mathrm{C}_{\text {DIC }}$. In areas 
of high productivity and low sediment carbonate concentration (c.a. 5\%) Mackensen and Licari (2003) explained the high $\delta^{13} \mathrm{C}$ offsets in C. wuellerstorfi with the undersaturation of the carbonate ion in deep waters. This is based in the effect that the carbonate ion concentration produces in both $\delta^{13} \mathrm{C}$ and $\delta^{18} \mathrm{O}$ fractionation in foraminifera (SPERO et al., 1997). Oligotrophic surface waters (BRANDINI, 2006), deep-sea sediment carbonate values (c.a. 18\%; BARIANI, personal communication) and the lack of positive $\delta^{18} \mathrm{O}$ offsets in C. wuellerstorfi (this study) suggests the carbonate ion effect is not influencing $\delta^{13} \mathrm{C}$ fractionation in the area. However, this needs further investigation. Thus, factors influencing this $\delta^{13} \mathrm{C}$ offset still need to be understood.

\section{ACKNOWLEDMENTS}

This work was supported financially by the Coordenação de Aperfeiçoamento de Pessoal de Nível Superior (CAPES). We thank Petrobras for providing the samples. The study benefited greatly from the comments of the two anonymous reviewers.

\section{REFERENCES}

ANTONOV, J. I.; LOCARNINI, R. A.; BOYER, T. P.; MISHONOV, A. V.; GARCIA, H. E. World Ocean Atlas, 2005, v. 2: Salinity. LEVITUS, S. (Ed.). NOAA Atlas NESDIS G2. Washington, D. C.: U.S Government Printing Office, 2006. 182 p.

BAINBRIDGE, A. E. GEOSECS Atlantic Expedition, Hydrographic Data, 1972-1973, v. 1. Washington, D.C.: US Government Printing Office, 1981.121 p.

BERGER, W. H.; KILLIKGLEY, J. S.; VINCENT, E. Stable isotopes in deep-sea carbonates: Box core ERDC-92, West Equatorial Pacific. Oceanol. Acta, v. 1, n. 2, p.203-215, 1978.

BILLUPS, K.; SPERO, H. J. Relationship between shell size, thickness and stable isotopes in individual planktonic foraminifera from two equatorial Atlantic cores. J. foram. Res., v. 25, n. 1, p. 24-37, 1995.

BRANDINI, F. P. Hidrografia e produção biológica na região sudeste-sul do Brasil no contexto do programa Revizee. In: ROSSI-WONGTSCHOWSKI, C.L.D.B.; MADUREIRA, L.S.-P. (Ed.). O Ambiente oceanográfico da plataforma continental e do talude na região sudeste-sul do Brasil. São Paulo: Edusp, 2006. p. 459-466.

CORLISS, B. H.; MCCORKLE, D. M.; HIGDON, D. M. A time series study of the carbon isotopic composition of deep-sea benthic foraminifera. Paleoceanography, v. 17, n. 3, p. 1-27, 2002

COSTA, K. B.; TOLEDO, F. A. L.; PIVEL, M. A. G.; MOURA, C. A. V.; CHEMALE, F. JR. Evaluation of two genera of benthic foraminifera for down-core paleotemperature studies in the western South Atlantic. Braz. J. Oceanogr., v. 54, n. 1, p. 75-84, 2006.
DEUSER, W. G.; ROSS, E. H.; HEMLEBEN, C.; SPLINDLER, M. Seasonal changes in species composition, numbers, mass, size, and isotopic composition of planktonic foraminifera settling into the deep Sargasso Sea. Palaeogeogr. Palaeoclimatol. Palaeoecol., v. 33, p. 103-127, 1981.

DUNBAR, R. B.; WEFER, G. Stable isotope fractionation in benthic foraminifera from the Peruvian continental margin. Mar. Geol., v. 59, p. 215-225, 1984.

ELDERFIELD, H.; VAUTRAVERS, M.; COOPER, M. The relationship between test size and $\mathrm{Mg} / \mathrm{Ca}$, $\mathrm{Sr} / \mathrm{Ca}, \quad \delta^{18} \mathrm{O}$ and $\delta^{13} \mathrm{C}$ of species of planktonic foraminifera. Geochem., Geophys., Geosystems, v. 3, n. $8,2002$.

GROSSMAN, E. T. Stable isotopes in modern benthic foraminifera: a study of vital effect. J. foram. Res., v. 17, n. 1, p. 48-61, 1987.

KIM, S. T.; O NEIL, J. R. Equilibrium and nonequilibrium oxygen isotope effects in synthetic carbonates. Geochim. cosmochim. Acta, v. 61, p. 3461-3475, 1997.

LEGRANDE, A. N.; SCHMIDT, G. A. Global gridded data set of the oxygen isotopic composition in seawater. Geophysical research letters, 33, L12604, doi:10.1029/2006GL026011, 2006.

LOCARNINI, R. A.; MISHONOV, A. V.; ANTONOV, J. I.; BOYER, T. P.; GARCIA, H. E. World Ocean Atlas, 2005, v. 1: Temperature. LEVITUS, S. (Ed.). NOAA Atlas NESDIS G1. Washington, D. C :U.S. Government Printing Office, 2006. $182 \mathrm{p}$.

MACKENSEN, A.; LICARI, L. Carbon isotopes of live benthic foraminifera from the South Atlantic: Sensitivity to bottom water carbonate saturation state and organic matter rain rates. In: WEFER, G.; MULITZA, S. RATMEYER, V. (Ed.). South Atlantic in the Late Quaternary: Reconstruction of material budgets and current systems. Berlin: Springer-Verlag, 2003. p. 623-644.

MCCORKLE, D. C.; HEGGIE, D. T.; VEEH, H. H. Glacial and Holocene stable isotope distribution in the southeastern Indian Ocean. Paleoceanography, v. 13, n. 1, p. 20-34, 1998.

MCCORKLE, D. C.; BERNHARD, J. M.; HINTZ, C. J.; BLANKS, J. K.; CHANDLER, G. T.; SHAW, T. J. The carbon and oxygen stable isotopic composition of cultured benthic foraminifera. Geolog. Soc., London, Special Publications, v. 303, p. 135-154, 2008.

OPPO, D. W.; FARIBANKS, R. G. Carbon isotope composition of tropical surface water during the past 22.000 years. Paleoceanography, v. 4, n. 4, p. 333-351, 1989.

OPPO, D. W.; HOROWITZ, M. Glacial deep water geometry: South Atlantic benthic foraminiferal $\mathrm{Cd} / \mathrm{Ca}$ and $\delta^{13} \mathrm{C}$ evidence. Paleoceanography, v. 15 , n. 2 , p. $147-160,2000$

RAVELO, A. C.; FAIRBANKS, R. G. Carbon isotopic fractionation in multiple species of planktonic foraminifera from core-tops in the Tropical Atlantic. J. foram. Res., v. 25, n. 1, p. 53-74, 1995.

ROHLING, E. J.; COOKE, S. 1999 Stable oxygen and carbon isotopes in foraminiferal carbonate shells. In Barun, K Sen Gupta (Ed.). Modern foraminifera. Kluwer Academic Publishers. Great Britain. 1999. p. 239-258. 
SILVEIRA, I, C; SCHMIDT, A. C. K; CAMPOS, E. J. GODOI, S. S.; IKEDA, Y. A corrente do Brasil ao largo da Costa Leste Brasileira. Rev. Bras. Oceanogr., . v. 48, n. 2, p. 171-183, 2000.

SCHMIEDL, G.; PFEILSTICKER, M.; HEMLEBEN, C.; MACKENSEN, A. Environmental and biological effects on the stable isotope composition of recent deep-sea benthic foraminifera from the western Mediterranean Sea. Mar. Micropaleontol., v. 51, p. 129-152, 2004.

SPERO, H. J.; BIJMA, J.; LEA, D. W.; BEMIS, B. E. Effect ion seawater carbonate concentration on the foraminiferal carbon and oxygen isotopes. Nature, v. 390, p. 497-500, 1997.

VINCENT, E.; KILLINGLEY, J. S.; BERGER, W. H. Stable isotope composition of benthic foraminifera from the equatorial Pacific. Nature, v. 289, p. 639-643, 1981.
WEFER, G.; BERGER, W. H.; BIJMA, J. \& FISCHER, G. Clues to Ocean History: a Brief Overview of Proxies. In: Fischer, G. Wefer, G (Eds.). Use of Proxies in Paleoceanography: Examples from the South Atlantic. Springer-Verlag Berlin Heidelberg, 1999, p. 168

WOLF-GLADROW, D. A.; BIJMA, J.; ZEEBE, R. E. Model simulation of the carbonate chemistry in the microenvironment of symbiont bearing foraminifera. Mar. Chem., v. 64, p. 181-198, 1999.

ZEEBE, R. E.; BIJMA, J.; WOLF-GLADROW, D. A. A diffusion-reaction model of carbon isotope fractionation in foraminifera. Mar. Chem., v. 64, p. 199-227, 1999.

(Manuscript received 21 October 2010; revised 25 April 2011; accepted 26 May 2011) 